\title{
IMPLEMENTASI MODEL PEMBELAJARAN JIGSAW UNTUK MENINGKATKAN KEAKTIFAN DAN HASIL BELAJAR SISWA KELAS X SMA PLUS 'BUSTANUL ULUM' PUGER JEMBER TAHUN AJARAN 2016/2017
}

\author{
${ }^{1)}$ Novita Kartika Sari, ${ }^{2)}$ Siti Halimatus S., ${ }^{3)}$ Roni Alim B.K; \\ 1) 2) ${ }^{3)}$ Universitas Kanjuruhan Malang \\ Email: ${ }^{1)}$ novitaks82@gmail.com; ${ }^{2}$ halimatus@unikama.ac.id; ${ }^{3)}$ roni_abk@yahoo.com.
}

\begin{abstract}
Abstrak
Keaktifan belajar siswa kelas X-D sangat rendah dan hasil ulangan harian dan ulangan tengah semester tahun pelajaran 2016/2017 pada semester genap masih belum memenuhi Kriteria Ketuntasan Minimal (KKM). Penelitian ini bertujuan untuk meningkatkan Keaktifan dan Hasil Belajar siswa kelas X-D SMA Plus 'Bustanul Ulum' Puger Jember melalui penerapan model pembelajaran Jigsaw. Penelitian ini menggunakan pendekatan kualitatif dengan jenis Penelitian Tindakan Kelas (PTK) yang dilakukan dalam dua siklus. Siklus 1 dengan pokok bahasan perairan darat, sedangkan pada siklus 2 dengan pokok bahasan perairan laut. Hasil penelitian menunjukkan bahwa untuk keaktifan siswa menunjukkan ketercapaian pada siklus 1 sebesar $67,7 \%$ yang berada pada kriteria aktif sedangkan pada siklus 2 mencapai $83,4 \%$ yang berada pada kriteria sangat aktif. Hal ini menunjukkan bahwa terjadi peningkatan dari siklus 1 ke siklus 2 yaitu sebesar $15,7 \%$. Hasil belajar pra tindakan rata-rata nilai siswa mencapai 53,3 dengan jumlah kentutasan klasikal $13,88 \%$, siklus 1 nilai rata-rata siswa mencapai 62,3 dengan jumlah ketuntasan klasikal $33,3 \%$, sedangkan pada siklus 2 mencapai 73,3 dengan jumlah ketuntasan klasikal 77,8\%. Ini menunjukkan bahwa antara pratindakan dan siklus 1 mengalami peningkatan sebesar $19,5 \%$ dan antara siklus 1 dan siklus 2 mengalami peningkatan sebesar 44,5\%. Berdasarkan hasil penelitian ini dapat disimpulkan bahwa implementasi pembelajaran model Jigsaw memenuhi kriteria sangat baik. Pembelajaran model Jigsaw meningkatkan keaktifan dan hasil belajar mata pelajaran geografi siswa kelas X-D SMA Plus 'Bustanul Ulum' Puger Jember.
\end{abstract}

Kata Kunci: Jigsaw, keaktifan, hasil belajar

\section{PENDAHULUAN}

SMA Plus 'Bustanul Ulum' Puger merupakan salah satu sekolah swasta di wilayah Selatan Jember yang memiliki akreditasi "A". Akan tetapi, dalam kegiatan pembelajarannya masih terdapat beberapa permasalahan yang harus segera dicarikan solusinya. Permasalahan tersebut berkaitan dengan rendahnya keaktifan dan hasil belajar siswa di SMA Plus 'Bustanul Ulum' Puger.

Keaktifan siswa yang rendah dalam proses pembelajaran sangat berpengaruh terhadap rendahnya hasil belajar siswa. Hal ini dibuktikan dengan dokumen yang ada pada guru mata pelajaran geografi kelas X-D bahwa, hasil ulangan harian, ulangan tengah semester dan ulangan semester tahun pelajaran 2016/2017 pada semester gasal masih belum memenuhi Kriteria Ketuntasan Minimum (KKM). KKM yang ditetapkan oleh guru mata pelajaran dan telah disetu-jui oleh sekolah adalah 73. Pada semester genap, pada ulangan harian pada KD 3.1 Menganalisis Litosfer dan Pedosfer serta dampaknya terhadap kehidupan di muka bumi dari 36 siswa hanya 5 siswa yang mencapai KKM dan 31 siswa lainnya masih belum mencapai KKM yang sudah ditetapkan. Pada hasil UTS semester genap, seluruh siswa kelas X-D menda- 
patkan nilai hasil belajar dibawah KKM yang sudah ditetapkan. Sedangkan kelas $\mathrm{X}$ yang lainnya masih ada yang mencapai nilai KKM yang sudah ditetapkan.

Model pembelajaran berfungsi sebagai pedoman bagi guru dalam merencanakan pembelajaran. Menurut Suprijono (2014:46) "Model pembela-jaran dapat didefinisikan sebagai kerangka konseptual yang melukiskan prosedur sistematis dalam mengorga-nisasikan pengalaman belajar untuk mencapai tujuan belajar".

Penelitian ini akan mengimplementasikan model pembelajaran Jigsaw atas pertimbangan latar belakang siswa di SMA Plus 'Bustanul Ulum' Puger Kabupaten Jember, antara lain: (1) Siswa sebagian besar kurang antusias dan lebih banyak pasif dalam mengikuti pemblajaran klasikal di kelas; (2) sebagian siswa masih bergantung teman yang pandai; (3) kerjasama kelompok belum optimal; (4) hasil belajar siswa rendah. Dengan penerapan model Jigsaw dalam pembelajaran geografi khususnya pada kelas X-D, diharapkan keaktifan dan hasil belajar siswa meningkat.

\section{METODE PENELITIAN}

Penelitian ini menggunakan pendekatan kualitatif dan jenis penelitian ini adalah Penelitian Tindakan Kelas (PTK) dengan menggunakan dua siklus model Kemmis and Mc Taggart. Siklus 1 dengan pokok bahasan perairan darat, sedangkan pada siklus 2 dengan pokok bahasan perairan laut.

Analisis data observasi keaktifan belajar yang dilakukan selama dan setelah pengumpulan data dengan menggunakan teknik analisis deskriptif kualitatif, yaitu dengan model penelitian yang bersifat menggambarkan kenyataan atau fakta sesuai dengan data yang diperoleh dengan tujuan untuk mengetahui keaktifan belajar siswa yang telah dicapai dalam tiap siklus. Adapun pedoman penskoran keaktifan belajar dengan menggunakan rumus sebagai berikut:

Nilai Keaktifan Individu $=\frac{\text { Skor yang diperoleh siswa }}{\text { shor maksimum }} \times 100 \%$

Tabel 1. Kriteria Penilaian Keaktifan Belajar Siswa

\begin{tabular}{lllc}
\hline No & $\begin{array}{l}\text { Nilai } \\
\text { Interval }\end{array}$ & Kategori & $\begin{array}{l}\text { Kriteria } \\
\text { dengan } \\
\text { huruf }\end{array}$ \\
1 & $80-100$ & $\begin{array}{l}\text { Sangat } \\
\text { Aktif }\end{array}$ & A \\
2 & $60-79$ & Aktif & B \\
3 & $40-59$ & Cukup & C \\
4 & $0-39$ & Aktif & Tidak \\
\multicolumn{5}{l}{ Aktif } \\
2016: 38)
\end{tabular}

Untuk menganalisis tingkat keberhasilan individu siswa dilihat dari nilai hasil belajar lebih dari KKM (Kriteria Ketuntasan Minimal) yang sudah ditetapkan yaitu 73. Persentase keberhasilan siswa setelah pembelajaran, dihitung dengan menggunakan rumus sebagai berikut:
Untuk menghitung nilai rata-rata setiap siswa dihitung dengan menggunakan rumus sebagai berikut:

$$
\text { Nilai rata-rata }=\frac{\text { jumlah total perolehan tes }}{\text { Jumlah siswa yang mengikuti tes }} \times 100 \%
$$

Data keterlaksanaan pembelajaran model Jigsaw diperoleh dari lembar observasi. Skor penilaian ditemukan dengan rumus persentase sebagai berikut: 
Tabel 2. Kriteria Penilaian Keterlaksanaan Pembelajaran Model Jigsaw

\begin{tabular}{cllc}
\hline No & $\begin{array}{l}\text { Nilai } \\
\text { Interval }\end{array}$ & Kategori & $\begin{array}{l}\text { Kriteria } \\
\text { dengan } \\
\text { huruf }\end{array}$ \\
\hline 1 & $90-100$ & $\begin{array}{l}\text { Sangat } \\
\text { Terlaksana }\end{array}$ & A \\
2 & $70-89$ & $\begin{array}{l}\text { Terlaksana } \\
\text { Cukup }\end{array}$ & B \\
3 & $50-69$ & $\begin{array}{l}\text { Terlaksana } \\
\text { Kurang } \\
4\end{array}$ & D \\
& $30-49$ & $\begin{array}{l}\text { Terlaksana } \\
\text { T. }\end{array}$ \\
\hline
\end{tabular}

Sumber: Nurkancana (dalam Mirati, 2016: 39)

Data kualitatif dari hasil catatan lapangan dianalisis dengan model deskriptif komparatif. Data hasil pengamatan setelah dianalisis dapat digunakan untuk menyusun refleksi.

\section{HASIL DAN PEMBAHASAN}

\section{Siklus I}

Siswa yang aktif biasanya ditandai dengan tingkah laku yang responsif dalam suatu proses pembelajaran. Keaktifan belajar siswa bisa dilihat dari interaksi stimulus dan responnya ketika guru memberikan materi. Menurut Watson (dalam Budiningsih, 2012:2) "Belajar adalah proses interaksi antara stimulus dan respon, namun stimulus dan respon yang dimaksud harus berbentuk tingkah laku yang dapat diamati (observable) serta dapat diukur. Skor keaktifan belajar diketahui selama pelaksanaan tindakan dengan menggunakan model Jigsaw pada matapelajaran geografi. Skor keaktifan belajar siswa dirubah kedalam bentuk nilai. Nilai keaktifan belajar pada siklus I dapat dilihat pada tabel 4.3 berikut:
Tabel 3 Nilai Keaktifan Belajar Siswa Siklus I

\begin{tabular}{cccc}
\hline No & Nilai & $\mathrm{f}$ & Persentase \\
& Interval & & \\
1 & $80-100$ & 9 & 25 \\
2 & $60-79$ & 21 & 58,3 \\
3 & $40-59$ & 3 & 8,3 \\
4 & $0-39$ & 3 & 8,3 \\
\hline
\end{tabular}

Berdasarkan tabel 3 dapat diketahui bahwa nilai keaktifan belajar siswa selama pelaksanaan tindakan siklus I, dari 36 siswa 9 orang siswa masuk dalam kategori sangat aktif, 21 siswa aktif, 3 siswa cukup aktif dan 3 orang tidak aktif. Rata-rata nilai keaktifan belajar siswa siklus I adalah 67,7 \% (kategori aktif) karena ada 3 siswa yang tidak hadir jadi nilai keaktifannya 0 atau mendapat kategori tidak aktif sehingga nilai ratarata kelas turun (secara lengkap data keaktifan belajar siswa siklus I pada lampiran 15a). Perbandingan nilai keaktifan belajar siswa siklus I disajikan dalam distribusi frekuensi bentuk grafik 1 berikut.

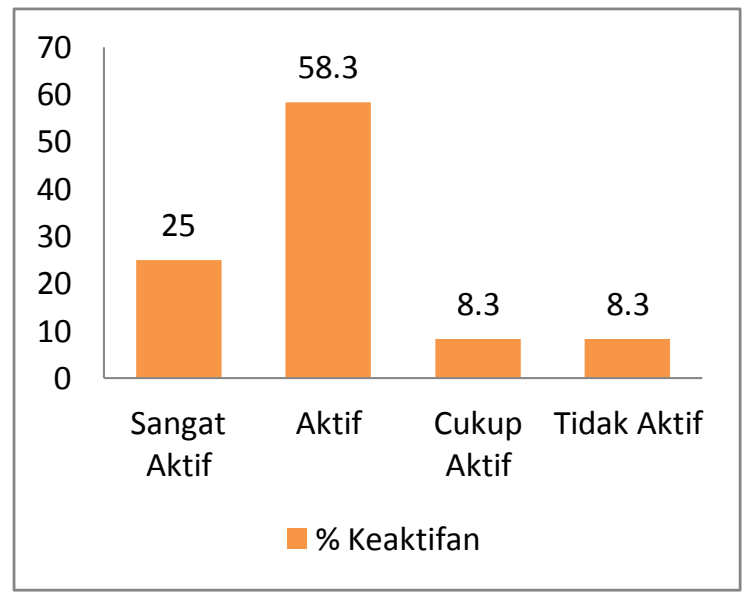

\section{Grafik 1 Frekuensi Keaktifan Belajar Siswa Siklus I}

Berdasarkan grafik 4.1 rata-rata keaktifan belajar siswa sudah menunjukkan aktif (secara lengkap rubrik kategori kektifan belajar siswa dapat dilihat pada lampiran 1). Akan tetapi, pada grafik frekuensi keaktifan belajar siswa siklus I masih ada siswa yang mendapat kategori cukup aktif dan tidak aktif. Hal ini menunjukkan 
bahwa siklus I harus diperbaiki, agar kesalahan dan kekurangan tersebut pada siklus II dapat dikurangi. Oleh karena itu peneliti harus mengevaluasi pembelajaran dari tindakan refleksi siklus I.

Hasil belajar memiliki arti yang berbeda baik oleh guru maupun siswa. Hasil belajar bisa dikatakan hasil dari proses interaksi dari guru dan siswa di dalam kelas. Menurut Dimyati dan Mudjiono (2013:3-4), hasil belajar merupakan hasil dari suatu interaksi tindak belajar dan tindak mengajar. Dari sisi guru, tindakan mengajar diakhiri dengan proses evaluasi hasil belajar. Dari sisi siswa, hasil belajar merupakan berakhirnya penggal dan puncak proses belajar.

Hasil belajar siswa diketahui setelah dilakukan tes uraian pada akhir siklus I pembelajaran model Jigsaw pada matapelajaran geografi. Nilai hasil belajar siswa kelas X-D secara klasikal pada matapelajaran geografi siklus I masih dibawah kriteria ketuntasan minimal yaitu $33,33 \%$. Rata-rata nilai hasil belajar siklus I adalah 65,25 dengan nilai tertinggi 95 dan terendah 35. Dari 36 siswa kelas X D, 12 siswa tuntas dan 24 siswa tidak tuntas atau nilai hasil belajarnya dibawah KKM yang ditetapkan yaitu 73. Hal ini menunjukkan bahwa siklus I harus diperbaiki, agar hasil belajar siswa meningkat pada siklus II. Oleh karena itu peneliti harus mengevaluasi pembelajaran dari tindakan refleksi siklus I.

\section{Siklus II}

Skor keaktifan belajar diketahui selama pelaksanaan tindakan dengan menggunakan model Jigsaw pada matapelajaran geografi. Skor keaktifan belajar siswa dirubah kedalam bentuk nilai. Nilai keaktifan belajar pada siklus II dapat dilihat pada tabel 4.4 berikut:
Tabel 4 Nilai Keaktifan Belajar Siswa Siklus II

\begin{tabular}{cccc}
\hline No & Nilai & $\mathrm{f}$ & Persentase \\
& Interval & & \\
1 & $80-100$ & 21 & 58,3 \\
2 & $60-79$ & 14 & 38,9 \\
3 & $40-59$ & 0 & 0 \\
4 & $0-39$ & 1 & 2,8 \\
\hline
\end{tabular}

Berdasarkan tabel 4 dapat diketahui bahwa nilai keaktifan belajar siswa selama pelaksanaan tindakan siklus II, dari 36 siswa 21 orang siswa masuk dalam kategori sangat aktif, 14 siswa aktif, dan 1 orang tidak aktif. Rata-rata nilai keaktifan belajar siswa siklus I adalah 83,4\% (kategori aktif) karena ada 1 siswa yang tidak hadir jadi nilai keaktifannya 0 atau mendapat kategori tidak aktif sehingga nilai rata-rata kelas. Perbandingan nilai keaktifan belajar siswa siklus II disajikan dalam distribusi frekuensi bentuk grafik 4.2 berikut.

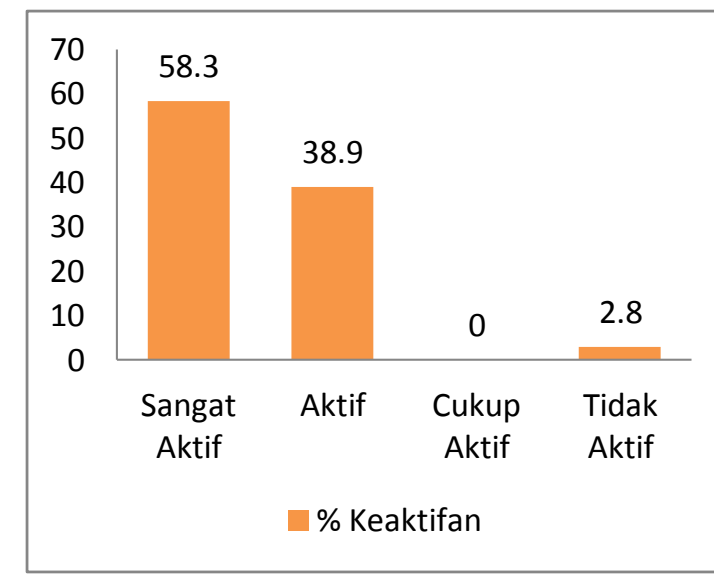

Grafik 2 Frekuensi Keaktifan Belajar Siswa Siklus II

Berdasarkan grafik 2 rata-rata keaktifan belajar siswa sudah menunjukkan sangat. Akan tetapi, pada grafik frekuensi keaktifan belajar siswa siklus II masih ada siswa yang mendapat kategori tidak aktif dikarenakan tidak hadir. Hal ini menunjukkan bahwa keaktifan belajar siklus II mengalami peningkatan dari siklus I. Hal ini diketahui dari peningkatan jumlah kategori siswa sangat 
aktif dan aktif, sedangkan kriteria siswa cukup aktif dan tidak aktif mengalami penurunan.

Hasil belajar siswa diketahui setelah dilakukan tes uraian pada akhir siklus II pembelajaran model Jigsaw pada matapelajaran geografi. Nilai hasil belajar siswa kelas X-D secara klasikal pada matapelajaran geografi siklus II sudah diatas kriteria ketuntasan minimal yaitu $77,8 \%$. Rata-rata nilai hasil belajar siklus I adalah 73,3 dengan nilai tertinggi 98 dan terendah 32. Dari 36 siswa kelas X-D, 28 siswa tuntas dan 8 siswa tidak tuntas atau nilai hasil belajarnya diatas KKM yang ditetapkan yaitu. Hal ini menunjukkan bahwa hasil belajar siklus II telah mengalami peningkatan dari siklus I. hal ini diketahui dari peningkatan jumlah siswa yang tuntas.

Berdasarkan hasil analisis keaktifan belajar pada setiap akhir siklus yaitu pada akhir siklus I dan siklus II. Keaktifan belajar siswa mengalami peningkatan dari siklus I ke siklus II adalah sebesar 15,7\% dengan cara membandingkan datanya masing-masing, selanjutnya membuat kesimpulan. Keaktifan belajar siswa ditunjukkan oleh enam indikator yaitu: merespon motivasi, membaca atau memahami masalah, menyelesaikan masalah atau menemukan jawaban, mengemukakan pendapat, berdiskusi atau bertanya, dan mempresentasikan hasil kerja kelompok. Peningkatan keaktifan belajar siswa setiap indikator selama penelitian dapat dilihat pada grafik 3 berikut ini:

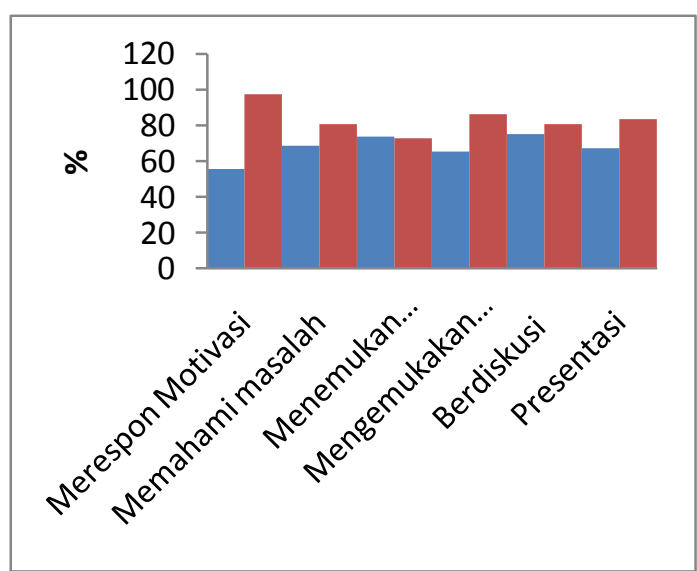

\section{Grafik 3 Frekuensi Peningkatan Keaktifan Belajar Siswa Setiap Indikator}

Grafik 4.3 menunjukkan bahwa terjadi peningkatan keaktifan belajar hampir pada semua indikator kecuali indikator menemukan jawaban. Peningkatan tiaptiap indikator dapat diketahui dengan cara membandingkan keaktifan belajar siklus I dan siklus II (data selengkapnya dapat dilihat pada lampiran 15a dan 16a).

Keaktifan belajar siswa setiap indikator pada siklus I termasuk kategori aktif. Ada beberapa hal yang menyebabkan keaktifan belajar siklus I lebih rendah dari pada siklus II, yaitu: 1) siswa baru pertama kali menggunakan pembelajaran model Jigsaw, 2) Kebiasaan siswa yang cenderung mengandalkan pada beberapa anggota kelompok saja dalam menyelesaikan LKS, dan 3) siswa malu untuk mempresentasikan hasil kerjanya di depan kelas.

Pada siklus II mulai ada peningkatan pada siswa ke arah kebaikan. Hal ini dikarenakan mereka mulai menyesuaikan diri dengan model pembelajaran dan ada perasaan kurang puas terhadap nilai hasil belajarnya. Pada siklus II hampir tejadi peningkatan pada semua indikator kecuali indikator menemukan jawaban. Pada indikator menemukan jawaban mengalami penurunan karena siswa dalam kegiatan tersebut hanya terpaku pada satu literatur saja yaitu buku geografi terbitan 
Erlangga tanpa mencoba mencari sumber literatur yang lain seperti pada siklus I.

Berdasarkan analisis nilai hasil belajar pada setiap akhir siklus yaitu pada akhir siklus I dan siklus II. Hasil belajar siswa mengalami peningkatan dari siklus I ke siklus II adalah sebesar 44,5\% dengan cara membandingkan datanya masingmasing, selanjutnya membuat kesimpulan. Hal ini sejalan dengan penelitian Chandra Adiputra, dkk (2015) yang menyatakan bahwa penerapan model pembelajaran kooperatif modifikasi model Jigsaw dapat meningkatkan hasil belajar di SMA Kristen Petra Malang.

Tercapainya peningkatan hasil belajar siswa ini karena dipengaruhi penerapan model Jigsaw dan kelebihan dari pembelajaran model Jigsaw sebagai karakteristik model ini. Peningkatan jumlah ketuntasa siswa berdasarkan hasil belajar siswa selama penelitian dapat dilihat pada grafik 4 berikut ini:

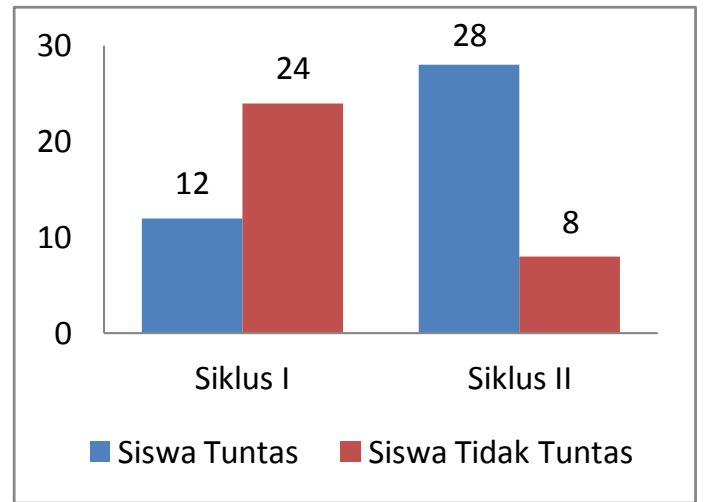

\section{Grafik 4 Frekuensi ketuntasan siswa siklus I dan siklus II}

Hasil belajar siswa pada siklus I, dari 36 siswa dikelas X D ada 12 siswa tuntas dan 24 siswa tidak tuntas atau nilai hasil belajarnya dibawah KKM yang ditetapkan yaitu 73. Hasil belajar siswa pada siklus II, dari 36 siswa dikelas X D ada 28 siswa tuntas dan 8 siswa tidak tuntas. Hal ini menunjukkan bahwa terjadi peningkatan jumlah siswa yang tuntas sebanyak 16 siswa.

\section{KESIMPULAN}

Keaktifan belajar siswa selama pembelajaran dengan model pembelajaran Jigsaw berdasarkan hasil observasi keaktifan siswa mengalami peningkatan dari siklus I ke siklus II. Hal tersebut ditunjukkan dengan kenaikan perolehan persentase keaktifan pada siklus I sebesar $67,7 \%$ dengan kriteria siswa aktif serta siklus II sebesar $83,4 \%$ dengan kriteria siswa aktif.

Keaktifan belajar siswa berpenga-ruh terhadap hasil belajar siswa. Hasil belajar siswa mengalami peningkatan dari pra tindakan ke siklus I dan siklus I ke siklus II. Peningkatan ini ditunjukkan dengan kenaikan hasil belajar siswa mulai dari pratindakan sebesar $13,88 \%$ siswa tuntas menjadi 33,33\% siswa tuntas pada siklus I. Pada siklus II kenaikan ketuntasan hasil belajar siswa kelas X-D menjadi $77,8 \%$. Sehingga dengan demikian penerapan model pembelajaran Jigsaw dapat meningkatkan hasil belajar siswa kelas XD pada mata pelajaran geografi.

\section{DAFTAR RUJUKAN}

Adiputra, Chandra., Sumarmi, \& Amirudin, Ach. 2015. Penerapan Pembelajaran Kooperatif Modifikasi Model Jigsaw Untuk Meningkatkan Hasil Belajar Siswa Kelas XI-IPS Di SMA Kristen Petra Malang. Makalah disajikan pada Seminar Nasional Pendidikan Universitas Muhammadiyah Ponorogo, Ponorogo, 7 November 2015 (online). (http://semnas.fkip.umpo.ac.id), diakses 18 Desember 2016.

Akbar, Sa'dun. 2010. Penelitian Tindakan Kelas. Yogyakarta. Cipta Media Aksara. 
Budiningsih, Asri, C. 2012. Belajar dan Pembelajaran. Jakarta. Rineka Cipta.

Dimyati dan Mudjiono. 2013. Belajar dan Pembelajaran. Jakarta: Rineka Cipta.

Mirati, Rosiana. 2016. Penerapan Model Pembelajaran Jigsaw Untuk Meningkatkan Keaktifan Dan Hasil Belajar Siswa Kelas VII-2 Pada Matapelajaran IPS Di SMP Negeri 3 Malang. Skripsi. Malang: FKIP Universitas Kanjuruhan Malang.

Suprijono, Agus. 2014. Cooperative Learning Teori dan Aplikasi PAIKEM. Yogyakarta. Pustaka Belajar. 